\title{
FAKTOR-FAKTOR YANG BERHUBUNGAN DENGAN PERILAKU SEKSUAL REMAJA SMA DI KOTA PONTIANAK
}

\author{
Veri \\ Program Studi S1 Keperawatan STIKes Widya Dharma Husada Tangerang \\ Email: stefenveri060991@wdh.ac.id
}

\begin{abstract}
ABSTRAK
Perilaku seksual adalah segala tingkah laku yang didorong oleh hasrat seksual baik yang dilakukan sendiri, dengan lawan jenis maupun sesama jenis tanpa adanya ikatan pernikahan. Perilaku seksual dipengaruhi oleh beberapa faktor diantaranya : pengetahuan, sikap, teman sebaya, usia pertama kali pacaran, jenis kelamin, frekuensi bertemu pacar, dan media informasi. Tujuan umum penelitian ini mengetahui tingkat pengetahuan remaja tentang faktor-faktor apa saja yang berhubungan dengan perilaku seksual remaja SMA di Pontianak. Penelitian ini menggunakan metode analitik observasional dengan rancangan cross-sectional. Hasil penelitian menunjukan variabel pengetahuan terhadap perilaku seksual ( $p$ value : $0,000<0,005$ ), variabel sikap terhadap perilaku seksual ( $p$ value : $0,000<0,005)$, variabel teman beresiko terhadap perilaku seksual ( $p$ value : 0,000<0,000), variabel jenis kelamin terhadap perilaku seksual ( $p$ value : 0,0,760>0,005), variabel frekuensi bertemu pacar terhadap perilaku seksual ( $p$ value : $0,001<0,005$ ), variabel media informasi terhadap perilaku seksual ( $p$ value : $0,930>0,005)$ dan variabel usia pertama kali pacaran terhadap perilaku seksual ( $p$ value : 0,202 >0,005). Hasil penelitian di atas, disimpulkan bahwa faktor pengetahuan, sikap, frekuensi bertemu pacar, teman sebaya memiliki hubungan terhadap perilaku seksual sedangkan usia pertama kali pacaran, jenis kelamin dan media informasi tidak memiliki hubungan terhadap perilaku seksual.
\end{abstract}

Kata kunci : Perilaku seksual, faktor resiko perilaku seksual

\begin{abstract}
Sexual behavior is any behavior that is driven by sexual desire either self-inflicted, with the opposite sex or the same sex without marriage. Sexual behavior is influenced by several factors, including : knowledge, attitudes, peers, age of first courtship, sex, frequency of meeting a boyfriend, and media information. The general objective of this research. Knowing the level of knowledge of adolescents about what factors are associated with adolescent sexual behavior of SMA in Pontianak. This study uses an observational analytic cross - sectional design. The results showed knowledge of the sexual behavior variables ( $p$ value : $0.000<$ 0.005), variable attitudes toward sexual behavior(p value : $0.000<0.005)$, variable Friends risk sexual behavior ( $p$ value : $0.000<0.000$ ), gender variable sexual behavior ( $p$ value : 0,0,760>0.005), variable frequency met girlfriend on sexual behavior ( $p$ value : $0.001<0.005)$, medium variable information on sexual behavior ( $p$ value : $0.930>0.005)$ and variable age of first courtship sexual behavior ( $p$ value : $0.202>0.005)$. Results of the above study, it was concluded that the factor of knowledge, attitudes, frequency of meeting a boyfriend, peers have been associated with sexual behavior while the age of first courtship, sex and the media does not have information on the relationship sexual behavior.
\end{abstract}

Keywords : Sexual behavior, Sexual behavioral factors 


\section{PENDAHULUAN}

Masa remaja merupakan masa peralihan dari kanak-kanak ke masa yang lebih dewasa. Kehidupan remaja merupakan kehidupan yang sangat menentukan bagi kehidupan masa depan mereka selanjutnya. Sekitar 1 miliar manusia atau setiap 1 di antara 6 penduduk dunia adalah remaja. Sebanyak $85 \%$ di antaranya hidup di Negara berkembang. Di Indonesia jumlah remaja dan kaum muda berkembang sangat cepat. Antara tahun 1997 dan 2000, kelompok umur 15-24 jumlahnya meningkat dari 21 jiwa menjadi 43 juta atau dari $18 \%$ menjadi $21 \%$ dari total jumlah populasi penduduk Indonesia (Wirdana, 2012).

Pada tahun 2010 jumlah remaja umur 10-24 tahun sangat besar yaitu sekitar 64 juta atau 27,6\% dari jumlah penduduk Indonesia sebanyak 237,6 juta jiwa (sensus penduduk, 2010). Melihat jumlahnya sangat besar, maka remaja sebagai generasi penerus bangsa perlu dipersiapakan menjadi manusia yang sangat sehat secara jasmani, rohani, mental dan spiritual. Faktanya berbagai penelitian menunjukan bahwa remaja mempunyai permasalahan yang sangat kompleks seiring dengan masa transisi yang dialami remaja. Masalah yang menonjol dikalangan remaja yaitu permasalahan seputar TRIAD KKR yaitu tiga resiko yang diadapi ole remaja (seksualitas, HIV, AIDS serta Napza), rendahnya pengetahuan remaja, pengaruh teman sebaya, kurangnya pengawasan orang tua serta kurangnya pendidikan agama yang diberikan membuat remaja terjerumus di dalam hal-hal yang negatif, salah satunya adalah penyimpangan perilaku seksual yang terkadang remaja sendiri kurang mengetahui apakah perilakunya tersebut baik atau buruk (Badan Kependudukan dan Keluarga Berencana Nasional).

Sebuah penelitian yang dilakukan oleh Dewan Kesehatan Midland (1996) yang mengeksplorasi praktek seksual dari 1.645 pria dan wanita (892 dan 762 masing-masing) berusia 16-18 tahun siswa sekolah menengah 12 sekolah yang dipilih secara acak dalam Dewan Kesehatan Midland. Penelitian ini melaporkan bahwa $32 \%$ dari 1.645 peserta menyatakan mereka melakukan hubungan seksual dan tidak ada perbedaan yang signifikan antara kelompok sosial - ekonomi. Penelitian ini juga menyoroti bahwa laki-laki secara signifikan lebih mungkin melakukan hubungan seksual daripada perempuan, dengan 38\% laki-laki dan 
$26 \%$ perempuan menyatakan mereka telah melakukan hubungan seksual. Penelitian menunjukan bahwa $75 \%$ dari 447 peserta yang menyatakan mereka memiliki hubungan seksual adalah antara usia 15 dan 17 tahun ketika mereka pertama kali melakukan hubungan seksual. Selain itu, $26 \%$ dari mereka yang memiliki hubungan seksual menyatakan mereka memiliki tiga atau lebih pasangan seksual.

Penelitian juga dilakukan oleh Aliansi (1997) mengeksplorasi sikap dan nilai-nilai remaja di Cork City terhadap seksualitas, hubungan, AIDS, alkohol dan penggunaan narkoba. Penelitian ini terdiri dari 800 remaja antara usia 15 dan 24. Empat kelompok fokus juga dilakukan. Hasil Penelitian menunjukkan bahwa 30\% dari peserta perempuan dan $45 \%$ dari peserta lakilaki dalam Kategori usia 15-17 tahun telah melakukan hubungan seksual. Selain itu, 22\% dari semua peserta perempuan dan $32 \%$ dari semua peserta laki-laki melakukan hubungan seksual pertama pada usia 16. Penelitian ini juga menunjukkan bahwa 81\% ( $=64)$ dari usia 15-17 tahun, perempuan aktif secara seksual telah memiliki dua pasangan seksual atau kurang, dan 46\% $(\mathrm{n}=24)$ dari usia 15 17 tahun laki-laki yang aktif secara seksual dilaporkan memiliki tiga pasangan seksual atau lebih.

Penelitian yang dilakukan oleh Wawan dan Dewi didapatkan hasil dari total 400 responden remaja SMA di Samarinda yang terdiri 192 pria dan 208 perempuan ternyata $14 \%$ nya pernah melakukan hubungan seksual saat berpacaran.

Penelitian juga dilakukan terhadap 633 siswa (345 pria dan 288 wanita) SMA di kota besar di Bali didapatkan bahwa $27 \%$ siswa pria mengaku pernah melakukan hubungan badan dengan lawan jenisnya dan $18 \%$ terjadi pada siswa putri (Pangkahila, W.1981).

Perubahan dan perkembangan pada masa remaja ditandai dengan munculnya tanda-tanda sekunder dan mulai matangnya organ-organ reproduksi. Menurut Freud dalam (Sadock, 1997) masa remaja sebagai fase genital, yaitu energi libido atau seksual yang pada masa pra remaja bersifat laten kini hidup kembali. Dorongan seks dicetuskan oleh hormon-hormon androgen tertentu seperti testosteron yang selama masa remaja ini kadarnya meningkat. Tidak jarang mereka melakukan masturbasi sebagai cara yang aman untuk memuaskan dorongan seksualnya, kadang-kadang mereka melakukan 
sublimasi terhadap dorongan seksualnya kearah aktifitas yang lebih bisa diterima, misalnya kearah sastra, psikologi, olah raga atau kerja sukarela, sistem sosial yang memadai sering membantu remaja menemukan cara-cara yang dapat menyalurkan energi seksualnya pada aktivitas atau peran yang lebih bisa diterima.

Pendapat Freud diatas diperkuat dengan pendapat Kaplan \& Sadock (1988) dalam bukunya Sinopsis Psikiatri, menurutnya pada fase remaja pertengahan berdasarkan literatur barat perilaku dan pengalaman seksual sudah menjadi kelaziman, dari waktu-kewaktu mereka makin dini melakukan aktivitas seksual (rata-rata telah melakukan pada usia 16 tahun). Baru pada masa remaja akhir mereka mulai ada perhatian terhadap rasa kasih sayang sesama manusia, moral, etika, agama, dan mereka mulai memikirkan masalah-masalah dunia (Sadock, 1997). Jelasnya citra tubuh, minat berkencan, dan perilaku seksual pada remaja sangat dipengaruhi oleh perubahan pada masa pubertas, yaitu suatu periode dimana kematangan fisik dan seksual terjadi secara pesat terutama pada awal masa remaja.

Jika ditinjau dari sisi perkembangan, minat remaja terhadap perilaku seks menurut Anna Freud (dalam Hurlock, 1990) didorong oleh meningkatnya keingintahuan remaja tentang seks. Remaja mencari berbagai macam informasi yang terkait dengan seks melalui bacaan, teman sebaya, atau mengadakan percobaan dengan melakukan masturbasi, bercumbu, atau bersenggama.

Berbagai temuan dari hasil penelitian yang dipaparkan pada pembahasan sebelumnya memberikan gambaran tentang perubahan pola perilaku seks remaja pada saat ini. Terkait dengan hal tersebut Anna Freud (dalam Hurlock, 1990) memberikan gambaran di dunia barat bahwa terjadi perubahan pola heteroseksualitas yang baru di kalangan remaja, sebagai contoh ciuman pada saat kencan pertama saat ini sudah dianggap biasa, padahal di masa lalu hal ini bisa merusak hubungan laki-laki dan perempuan yang baru mulais

Selain itu, Anna freud ( dalam Hurlock 1980) dalam memaparkan bahwa perubahan perilaku seksual tampak menonjol, namun perubahan sikap seksual lebih menonjol lagi. Perilaku yang pada generasi yang lalu akan mengejutkan para remaja bila terjadi diantara teman-teman sebayanya, dan akan menimbulkan rasa malu dan bersalah bila terjadi dalam kehidupan mereka sendiri, sekarang dianggap benar 
dan normal, atau paling sedikit diperbolehkan. Bahkan hubungan seks sebelum nikah dianggap "benar" apabila dilakukan dengan rasa cinta. Menurut para remaja saat ini, hubungan seksual yang dilakukan dengan kasih sayang lebih diterima daripada bercumbu hanya sekedar melepas nafsu.

Banyak faktor yang berhubungan dengan perilaku seksual remaja tersebut di antaranya perubahan biologis yang terjadi pada masa pubertas dan pengaktifan hormonal dapat menimbulkan perilaku seksual, kurangnya pengaruh orangtua melalui komunikasi antara orangtua dan remaja seputar masalah seksual dapat memperkuat munculnya penyimpangan perilaku seksual (Oom,1981) (dalam Kusmiran 2012), pengaruh teman sebaya sangat kuat sehingga munculnya penyimpangan perilaku seksual dikaitkan dengan norma kelompok sebaya, remaja dengan prestasi rendah dan tahap aspirasi yang rendah cendrung lebih sering memunculkan aktivitas seksual dibandingkan remaja dengan prestasi yang baik di sekolah (prespektif akademik), perspektif sosial kognitif diasosiasikan dengan pengambilan keputusan yang menyediakan pemahaman perilaku seksual kalangan remaja (Muss,1990). Selain itu faktor frekuensi pertemuan dengan pacar mempengaruhi perilaku seksual pada remaja yaitu pada masa ini remaja berkesempatan untuk melakukan pertemuan yang sering, sehingga dapat meningkatkan resiko melakukan hubungan seksual.

Faktor yang dapat mempengaruhi seorang remaja melakukan perilaku seksual karena ia didorong oleh rasa ingin tahu yang besar untuk mencoba segala hal yang belum diketahui. Hal tersebut merupakan ciri-ciri remaja pada umumnya, mereka ingin mengetahui banyak hal yang hanya dapat dipuaskan serta diwujudkannya melalui pengalaman mereka sendiri (Kusmiran 2012). Disinilah suatu masalah muncul dalam kehidupan remaja karena mereka ingin mencoba-coba segala hal, termasuk yang berhubungan dengan fungsi ketubuhannya yang juga melibatkan pasangannya. Namun dibalik itu semua, faktor internal yang paling mempengaruhi perilaku seksual remaja sehingga mengarah pada perilaku seksual pada remaja adalah berkembangnya organ seksual. Dikatakan bahwa gonads (kelenjar seks) yang tetap bekerja (seks primer) bukan saja berpengaruh pada penyempurnaan tubuh (khususnya yang berhubungan dengan ciri-ciri seks sekunder), melainkan juga berpengaruh jauh pada kehidupan psikis, moral, dan sosial. 
Pada kehidupan psikis remaja, perkembangan organ seksual mempunyai pengaruh kuat dalam minat remaja terhadap lawan jenis kelamin. Ketertarikkan antar lawan jenis ini kemudian berkembang ke pola kencan yang lebih serius serta memilih pasangan kencan dan romans yang akan ditetapkan sebagai teman hidup, sedangkan pada kehidupan moral, seiringan dengan bekerjanya gonads, tak jarang timbul konflik dalam diri remaja. Masalah yang timbul yaitu akibat adanya dorongan seks dan pertimbangan moral sering kali bertentangan. Bila dorongan seks terlalu besar sehingga menimbulkan konflik yang kuat, maka dorongan seks tersebut cenderung untuk dimenangkan dengan berbagai dalih sebagai pembenaran diri. Jersild (1978) mengungkapkan jika remaja bercerita tentang kegiatan seksual mereka, maka mereka banyak membela diri dengan komentar "Everybody does it."

Faktor lingkungan, yang memiliki peran yang tidak kalah penting dengan faktor pendorong perilaku seksual lainnya. Faktor lingkungan ini bervariasi macamnya, ada teman sepermainan (peer-group), pengaruh media dan televisi, bahkan faktor orang tua sendiri. Pada masa remaja, kedekatannya dengan peer-groupnya sangat tinggi karena selain ikatan peergroup menggantikan ikatan keluarga, mereka juga merupakan sumber afeksi, simpati, dan pengertian, saling berbagi pengalaman dan sebagai tempat remaja untuk mencapai otonomi dan independensi (Papalia, 2001). Maka tak heran bila remaja mempunyai kecenderungan untuk mengadopsi informasi yang diterima oleh temantemannya, tanpa memiliki dasar informasi yang signifikan dari sumber yang lebih dapat dipercaya. Informasi dari teman-temannya tersebut, dalam hal ini sehubungan dengan perilaku seksual, tak jarang menimbulkan rasa penasaran yang membentuk serangkaian pertanyaan dalam diri remaja. Untuk menjawab pertanyaan itu sekaligus membuktikan kebenaran informasi yang diterima, mereka cenderung melakukan dan mengalami perilaku seks itu sendiri.

Pengaruh media dan televisi pun sering kali diimitasi oleh remaja dalam perilakunya sehari-hari. Misalnya saja remaja yang menonton film remaja yang berkebudayaan barat, melalui observational learning, mereka melihat perilaku seks itu menyenangkan dan dapat diterima lingkungan. Hal ini pun diimitasi oleh mereka, terkadang tanpa memikirkan adanya perbedaan 
kebudayaan, nilai serta norma-norma dalam lingkungan masyakarat yang berbeda.

Perilaku yang tidak sesuai dengan tugas perkembangan remaja pada umumnya dapat dipengaruhi orang tua. Bilamana orang tua mampu memberikan pemahaman mengenai perilaku seks kepada anak-anaknya, maka anakanaknya cenderung mengontrol perilaku seksnya itu sesuai dengan pemahaman yang diberikan orang tuanya. Hal ini terjadi karena pada dasarnya pendidikan seks yang terbaik adalah yang diberikan oleh orang tua sendiri, dan dapat pula diwujudkan melalui cara hidup orang tua dalam keluarga sebagai suami-istri yang bersatu dalam perkawinan (Aryatmi, 1991) dalam bukunya Perspektif Bimbingan konseling. Kesulitan yang timbul kemudian adalah apabila pengetahuan orang tua kurang memadai menyebabkan sikap kurang terbuka dan cenderung tidak memberikan pemahaman tentang masalah-masalah seks anak. Akibatnya anak mendapatkan informasi seks yang tidak sehat. Davis (1957) (dalam Hamid Hasan, 1990) dalam penelitiannya menyimpulkan sebagai berikut: informasi seks yang tidak sehat atau tidak sesuai dengan perkembangan usia remaja ini mengakibatkan remaja terlibat dalam kasus-kasus berupa konflik-konflik dan gangguan mental, ide-ide yang salah dan ketakutan-ketakutan yang berhubungan dengan seks (Bibby, 1957) dalam bukunya Sek Education. Dalam hal ini, terciptanya konflik dan gangguan mental serta ide-ide yang salah dapat memungkinkan seorang remaja untuk melakukan perilaku seksual. Keterangan salah satu guru, belum pernah ada penelitian tentang perilaku seksual remaja di dua SMA Negeri di Kota Pontianak, dan dua SMA Negeri ini belum mempunyai Pusat Informasi dan Konseling Remaja (PIK-R). Terdapat guru Bimbingan Penyuluhan / Bimbingan Konseling (BP/BK), terdapat masingmasing 1 guru BP/BK. Salah satu guru Bimbingan Konseling mengatakan pernah ada siswa yang hamil beberapa tahun yang lalu dan kemudian siswa tersebut di keluarkan dari sekolah tersebut.

Berdasarkan observasi awal yang dilakukan peneliti di dua SMA Negeri 5 dan SMA Rahadi Osman Pontianak, yang sebenarnya peneliti akan mengadakan di 5 SMA Negeri di Kota Pontianak, namun yang bersedia dimintai data dan bersedia menjadi tempat untuk meneliti hanya dua SMA yaitu SMA Negeri 6 dan SMA Rahadi Osman Pontianak. Dari 20 siswa yang menjadi responden menyatakan pernah punya pacar dan pertama kali pacaran pada umur di bawah 15 tahun, 20 
siswa mengatakan saat ini punya pacar. 15 siswa dari 20 siswa menyatakan pernah melakukan aktivitas seksual, seperti berpegangan tangan 16 orang, berciuman 6 orang, meraba 4 orang, berpelukan 10 orang.

Hal ini yang menjadi alasan ketertarikan peneliti mengambil lokasi penelitian di SMA Negeri 6 dan SMA Rahadi Osman Pontianak, mengenai Faktor-Faktor yang Berhubungan dengan Perilaku Seksual Remaja di SMA di Kota Pontianak Tahun 2013.

\section{METODE PENELITIAN}

Pada penelitian ini, subjek yang diambil oleh peneliti adalah individu dewasa dengan rentang usia 15-18 tahun, siswa sisawi SMA di kota Pontianak. Lokasi pengambilan sampel diadakan di SMA Negeri 06 Pontianak dan SMA Rahadi Osman Pontianak. Pengambilan sampel menggunakan tehnik Random Sampling.

\section{HASIL DAN PEMBAHASAN}

Penyajian data khusus meliputi variabel bebas yaitu tingkat pengetahuan, sikap, usia pertamakali pacaran, frekuensi bertemu pacar, teman sebaya, jenis kelamin dan media informasi sedangkan variabel terikatnya tentang perilaku seksual remaja. Untuk mengetahui signifikansi atau hubungan antara variabel dilakukan uji statistik dengan bantuan softwere komputer dengan tingkat kemaknaan $\rho<0,05$, ketentuan terhadap penerimaan dan penolakan hipotesis apabila signifikansi $\rho<0,05$, maka Ha gagal ditolak dan Ho ditolak, apabila $\rho>0,05$ maka Ha ditolak dan Ho gagal ditolak.

Hasil penelitian ini disajikan berupa data primer yang kemudian di analisis dalam dua tahap, yaitu analisis univariat yang mendeskripsikan variabel bebas dan variabel terikat dan hasil penelitian bivariat yakni mendeskripsikan hubungan antara variabel bebas dan variabel terikat yang dianalisa dengan menggunakan correlate dan chi-square.

Hasil penelitian yang dilakukan ditemukan adanya hubungan pengetahuan terhadap perilaku seksual remaja di SMA Negeri 06 Pontianak dan SMA Rahadi Osman yang ditunjukkan oleh $(\rho$ value $=0.000<0.05)$ dan $\mathrm{OR}=$ 6,740. Hasil analisis bivariat menunjukkan bahwa remaja di SMA Negeri 06 dan SMA Rahadi Osman yang memiliki pengetahuan yang baik dan beresiko berperilaku seksual sebanyak $10,2 \%$. Kemudian remaja yang memiliki pengetahuan kurang dan beresiko berperilaku seksual sebanyak 56,6\%. Penelitian ini didukung oleh penelitian yang dilakukan oleh Anna Freud (dalam 
Hurlock, 1990) yang mengemukakan semakin tinggi pengetahuan seorang remaja semakin tinggi pula keinginan remaja untuk mengetahui tentang sek, remaja mencari berbagai informasi yang terkait dengan seks melalui bacaan, teman sebaya atau mengadakan percobaan dengan melakukan masturbasi, bercumbu dan bersenggama.

Analisa data lebih lanjut menyimpulkan bahwa remaja yang memiliki pengetahuan kurang baik 6,740 kali lebih cenderung untuk berperilaku seksual dibandingkan dengan remaja yang memiliki pengetahuan baik.

Teori yang mendukung yaitu pengetahuan merupakan segala sesuatu yang diketahuai oleh seseorang yang didapat dari pengalaman, berbagai informasi, percobaan baik secara sengaja maupun tidak sengaja sebagai hasil dari penggunaan panca inderanya

Berdasarkan paparan penjelasan dan teori-teori diatas bahwa Ha gagal ditolak dengan nilai signifikan $(\rho$ value $=0.000<$ 0.05) berarti ada hubungan antara pengetahuan remaja terhadap perilaku seksual remaja di SMA N 06 Pontianak dan SMA Rahadi Osman.

Hasil analisis bivariat menunjukkan bahwa remaja di SMA Negeri 06 Pontianak dan SMA Rahadi Osman yang memiliki sikap mendukung dan beresiko berperilaku seksual sebanyak 10,1\% .
Kemudian remaja yang memiliki sikap tidak mendukung dan beresiko berperilaku seksual sebanyak $68,7 \%$. Hasil penelitian yang dilakukan ditemukan adanya hubungan siakap terhadap perilaku seksual remaja di SMA Negeri 06 Pontianak dan SMA Rahadi Osman yang ditunjukkan oleh $(\rho$ value $=0.000<0.05)$ dan $\mathrm{OR}=$ 4,039. Hal ini didukung oleh Anna Freud yang memaparkan bahwa perubahan perilaku seksual tampak menonjol, namun perubahan sikap seksual lebih menonjol lagi. Bahkan remaja menganggap berhubungan sek sebelum nikah dianggap benar apabila dilakukan dengan rasa cinta. Menurut remaja saat ini, hubungan seksual yang dilakukan dengan kasih saying lebih diterima daripada bercumbu hanya sekedar melepas nafsu.

Teori yang mendukung yaitu sikap merupakan reaksi atau respon seseorang terhadap suatu stimulus atau objek. Sikap dalam kehidupan sehari-hari adalah merupakan reaksi yang bersifat emosional terhadap stimulus sosial. Sikap belum merupakan suatu tindakan atau aktivitas, akan tetapi merupakan predisposisi tindakan atau perilaku (Mubarak, 2007).

Analisa data lebih lanjut menyimpulkan bahwa remaja yang memiliki sikap tidak mendukung 4,039 kali lebih cenderung untuk berperilaku seksual dibandingkan dengan remaja yang memiliki sikap mendukung. Hal ini 
dipengaruhi adanya faktor lain yang mempengaruhi perilaku seksual. Berdasarkan paparan penjelasan dan teori-teori diatas bahwa Ha gagal ditolak dengan nilai signifikan $(\rho$ value $=0.000$ $<0.05)$ berarti ada hubungan antara sikap terhadap perilaku seksual remaja di SMA Negeri 06 Pontianak dan SMA Rahadi Osman.

Hasil analisis bivariat menunjukkan bahwa remaja di SMA Negeri 06 Pontianak dan SMA Rahadi Osman yang bertemu pacarnya tiga kali seminggu atau lebih dan beresiko berperilaku seksual sebanyak 85,6\%. Kemudian remaja yang bertemu pacarnya kurang dari tiga kali seminggu dan beresiko berperilaku seksual sebanyak $31,5 \%$. Hasil penelitian yang dilakukan ditemukan adanya hubungan frekuensi bertemu pacar terhadap perilaku seksual remaja di SMA Negeri 06 Pontianak dan SMA Rahadi Osman yang ditunjukkan oleh $(\rho$ value $=0.001<0.05)$ dan $\mathrm{OR}=$ 0,367 . Hal ni didukung dengan yang dikemukakan oleh (Muss,1990) yaitu salah satu frekuensi bertemu dengan pacar mempengaruhi perilaku seksual pada remaja yaitu pada masa ini remaja berkesempatan untuk melakukan pertemuan yang sering, sehingga dapat meningkatkan resiko melakukan hubungan seksual.
Analisa data lebih lanjut menyimpulkan bahwa remaja yang bertemu pacarnya tiga kali seminggu atau lebih 0,367 kali lebih cenderung untuk berperilaku seksual dibandingkan dengan remaja yang bertemu pacarnya kurang dari tiga kali seminggu. Hal ini dipengaruhi adanya faktor lain yang mempengaruhi perilaku seksual.

Teori yang mendukung salah satu faktor yang mempengaruhi perilaku seksual remaja yaitu frekuensi bertemu dengan pacar mempengaruhi perilaku seksual pada remaja yaitu pada masa ini remaja berkesempatan untuk melakukan pertemuan yang sering, sehingga dapat meningkatkan resiko melakukan hubungan seksual.

Berdasarkan paparan penjelasan dan teori-teori diatas bahwa Ha gagal ditolak dengan nilai signifikan $(\rho$ value $=0.001$ $<0.05)$ berarti ada hubungan antara frekuensi bertemu pacar terhadap perilaku seksual remaja di SMA Negeri 06 Pontianak dan SMA Rahadi Osman.

Hasil analisis bivariat menunjukkan bahwa remaja di SMA Negeri 06 Pontianak dan SMA Rahadi Osman yang memiliki teman sebaya beresiko dan beresiko berperilaku seksual sebanyak $89,2 \%$. Kemudian remaja yang memiliki teman sebaya yang tidak beresiko dan beresiko berperilaku seksual sebanyak $34,0 \%$. Hasil penelitian yang dilakukan 
ditemukan adanya hubungan teman sebaya terhadap perilaku seksual remaja di SMA Negeri 06 Pontianak dan SMA Rahadi Osman yang ditunjukkan oleh $(\rho$ value $=0.000<0.05)$ dan $\mathrm{OR}=16,043$. Hal ini didukung oleh Oom,1981 yang mengemukakan pengaruh teman sebaya sangat kuat sehingga munculnya penyimpangan perilaku seksual.

Analisa data lebih lanjut menyimpulkan bahwa remaja yang memiliki teman sebaya beresiko 16,043 kali lebih cenderung untuk berperilaku seksual dibandingkan dengan remaja yang memiliki teman sebaya yang tidak beresiko. Hal ini dipengaruhi adanya faktor lain yang mempengaruhi perilaku seksual.

Teori yang mendukung hal tersebut yaitu informasi mengenai hubungan seksual yang diperoleh dari teman sebaya sedikit banyak telah memberikan dorongan untuk menentukan sikap remaja dalam melakukan interaksi dengan pasangan selain itu dukungan teman sebaya menjadi salah satu sumber informasi yang cukup signifikan dalam membentuk pengetahuan seksual di kalangan remaja.

Berdasarkan paparan penjelasan dan teori-teori diatas bahwa Ha gagal ditolak dengan nilai signifikan $(\rho$ value $=0.000$ $<0.05)$ berarti ada hubungan antara teman sebaya terhadap perilaku seksual remaja di SMA Negeri 06 Pontianak dan SMA Rahadi Osman.

Hasil analisis bivariat menunjukkan bahwa remaja di SMA Negeri 06 Pontianak dan SMA Rahadi Osman yang memiliki jenis kelamin perempuan dan beresiko berperilaku seksual sebanyak $80,4 \%$. Kemudian remaja yang memiliki jenis kelamin laki-laki dan beresiko berperilaku seksual sebanyak 78,8\%. Hasil penelitian yang dilakukan ditemukan tidak adanya hubungan jenis kelamin terhadap perilaku seksual remaja di SMA Negeri 06 Pontianak dan SMA Rahadi Osman yang ditunjukkan oleh ( $\rho$ value $=0,760<0.05)$ dan $\mathrm{OR}=0,907$. Hal ini didukung oleh penelitian yang dilakukan oleh Wawan dan Dewi yaitu hasil penelitian menunjukan dari 400 responden remaja SMA di Samarinda yang terdiri dari 192 pria dan 208 perempuan ternyata ternyata $14 \%$ nya pernah melakukan hubungan seksual saat berpacaran.

Analisa data lebih lanjut menyimpulkan bahwa remaja yang memiliki jenis kelamin perempuan 0,907 kali lebih cenderung untuk berperilaku seksual dibandingkan dengan remaja yang memiliki jenis kelamin laki-laki. Hal ini dipengaruhi adanya faktor lain yang mempengaruhi perilaku seksual.

Teori yang mendukung hal tersebut yaitu menurut Gunasa (1991) dalam 
hubungan denga lawan jenis, laki-laki cendrung agresif sedangkan perempuan cendrung lebih pasif, ketertarikan remaja laki-laki terhadap lawan jenis lebih kepada keinginan untuk memuskan hasrat seksualnya, sedangkan perempuan lebih pada panggilan aspek personaliti.

Berdasarkan paparan penjelasan dan teori-teori diatas bahwa $\mathrm{Ha}$ ditolak dengan nilai signifikan $(\rho$ value $=0,760$ $>0.05)$ berarti tidak ada hubungan antara jenis kelamin terhadap perilaku seksual remaja di SMA Negeri 06 Pontianak dan SMA Rahadi Osman.

Hasil analisis bivariat menunjukkan bahwa remaja di SMA Negeri 06 Pontianak dan SMA Rahadi Osman yang terpapar media informasi kesehatan reproduski dan beresiko berperilaku seksual sebanyak 80,0\%. Kemudian remaja yang tidak terpapar media informasi kesehatan reproduksi dan beresiko berperilaku seksual sebanyak $79,3 \%$. Hasil penelitian yang dilakukan ditemukan tidak adanya hubungan media informasi kesehatan reproduksi terhadap perilaku seksual remaja di SMA Negeri 06 Pontianak dan SMA Rahadi Osman yang ditunjukkan oleh $(\rho$ value $=0,930>$ $0.05)$ dan $\mathrm{OR}=1,043$. Hal ini didukung oleh penelitian yang mengemukakan pengaruh internet dan televisipun seringkali di intimidasi oleh remaja dalam perilakunya sehari-hari, misalnya remaja yang menonton film yang berkebudayaan barat, mereka melihat perilaku seksual itu menyenangkan dan dapat di terima di kalangan remaja.

Analisa data lebih lanjut menyimpulkan bahwa remaja yang terpapar media informasi kesehatan reproduksi 1,043 kali lebih cenderung untuk berperilaku seksual dibandingkan dengan remaja yang tidak terpapar media informasi kesehatan reproduksi. Nilai korelasi 0,005 yang berarti hubungan kedua variabel ini tidak kuat dan ke arah positif. Hal ini dipengaruhi adanya faktor lain yang memepengaruhi perilaku seksual.

Teori yang mendukung hal ini yaitu media masa yang disampaikan secara terbuka dalam bentuk pesan sederhana sampai sangat kompleks akan menambah pengetahuan seseorang serta akan mempengaruhi seseorang dalam mengambil sikap untuk mengambil keputusan bertindak dengan positif.

Berdasarkan paparan penjelasan dan teori-teori diatas bahwa Ha ditolak dengan nilai signifikan $(\rho$ value $=0,930$ $<0.05)$ berarti tidak ada hubungan antara media informasi kesehatan reproduksi terhadap perilaku seksual remaja di SMA Negeri 06 Pontianak dan SMA Rahadi Osman. 


\begin{abstract}
Hasil analisis bivariat menunjukan bahwa remaja usia pertamakali pacarannya rata-rata berusia 14,65 tahun dengan standar deviasi 1,637 tahun. Usia termuda remaja pertamakali pacaran yaitu 12 tahun dan usia tertua remaja pertamakali pacaran yaitu 18 tahun.

Berdasarkan paparan penjelasan dan teori-teori diatas bahwa $\mathrm{Ha}$ ditolak dengan nilai signifikan ( $\rho$ value $=0,202>0.05)$ berarti tidak ada hubungan antara usia pertama kali pacaran terhadap perilaku seksual remaja di SMA Negeri 06 Pontianak dan SMA Rahadi Osman. Hal ini didukung oleh penelitian yang mengemukakan bahwa $75 \%$ dari 447 peserta yang menyatakan mereka memiliki hubungan seksual adalah usia 15 dan 17 tahun ketika mereka pertama kali melakukan hubungan seksual. Menurut Freud rata-rata usia remaja pertama kali pacaran saat berusia 16 tahun (Dewan Kesehatan Miland).
\end{abstract}

\section{KESIMPULAN}

Berdasarkan tujuan penelitian yang diharapkan, maka dapat ditarik kesimpulan sebagai berikut:

Frekuensi pengetahuan remaja di SMA N 06 Pontianak dan SMA
Rahadi Osman yang kurang baik sebanyak 83 remaja atau $29,7 \%$ dan yang baik sebanyak 196 remaja atau $70,3 \%$.

Frekuensi sikap remaja di SMA N 06 Pontianak dan SMA Rahadi Osman yang tidak mendukung sebanyak 131 remaja atau $47,0 \%$ dan yang mendukung sebanyak 148 remaja atau $53,0 \%$.

Frekuensi bertemu pacar remaja di SMA N 06 Pontianak dan SMA Rahadi Osman yang kurang dari 3 kali seminggu sebanyak 92 remaja atau $33,0 \%$ dan yang 3 kali seminggu atau lebih sebanyak 187 remaja atau $67,0 \%$.

Frekuensi Teman sebaya di SMA N 06 Pontianak dan SMA Rahadi Osman yang beresiko sebanyak 232 remaja atau $83,2 \%$ dan yang tidak beresiko sebanyak 47 remaja atau $16,8 \%$.

Frekuensi jenis kelamin remaja di SMA N 06 Pontianak dan SMA Rahadi Osman yang laki-laki sebanyak 85 remaja atau $30,5 \%$ dan yang perempuan sebanyak 194 remaja atau $69,5 \%$.

Frekuensi media informasi kesehatan reproduksi di SMA N 06 Pontianak dan SMA Rahadi Osman yang terpapar sebanyak 250 remaja 
atau $89,6 \%$ dan yang tidak terpapar sebanyak 29 remaja atau 10,4\%.

Frekuensi usia pertama kali pacaran di SMA N 06 Pontianak dan SMA Rahadi Osman dijelaskan bahwa remaja usia pertamakali pacarannya rata-rata berusia 14,71 tahun dengan standar deviasi 1,644 tahun. Usia termuda remaja pertamakali pacaran yaitu 12 tahun dan usia tertua remaja pertamakali pacaran yaitu 18 tahun.

Ada hubungan antara pengetahuan remaja terhadap perilaku seksual remaja di SMA N06 Pontianak dan SMA Rahadi Osman dengan nilai signifikan $(\rho$ value $=$ $0.000<0.05)$ berarti Ha gagal ditolak dan Ho ditolak.

Ada hubungan antara sikap remaja terhadap perilaku seksual remaja di SMA N 06 Pontianak dan SMA Rahadi Osman dengan nilai signifikan $(\rho$ value $=0.000<0.05)$ berarti Ha gagal ditolak dan Ho ditolak.

Ada hubungan antara frekuensi bertemu pacar terhadap perilaku seksual remaja di SMA N 06 Pontianak dan SMA Rahadi Osman dengan nilai signifikan $(\rho$ value $=$ $0.001<0.05)$ berarti Ha gagal ditolak dan Ho ditolak.

Ada hubungan antara teman sebaya terhadap perilaku seksual remaja di SMA N 06 Pontianak dan SMA Rahadi Osman dengan nilai signifikan $(\rho$ value $=0.000<0.05)$ berarti Ha gagal ditolak dan Ho ditolak.

Tidak ada hubungan antara jenis kelamin remaja terhadap perilaku seksual remaja di SMA N 06 Pontianak dan SMA Rahadi Osman dengan nilai signifikan $(\rho$ value $=0.760>0.05)$ berarti Ha ditolak dan Ho gagal ditolak.

Tidak ada hubungan antara media informasi kesehatan reproduksi terhadap perilaku seksual remaja di SMA N 06 Pontianak dan SMA Rahadi Osman dengan nilai signifikan ( $\rho$ value $=0,930$ $>0.05)$ berarti Ha ditolak dan Ho gagal ditolak.

Tidak ada hubungan antara usia pertama kali pacaran terhadap perilaku seksual remaja di SMA N 06 Pontianak dan SMA Rahadi Osman dengan nilai signifikan $(\rho$ value $=0.202>0.05)$ berarti Ha ditolak dan Ho gagal ditolak.

\section{DAFTAR PUSTAKA}

Aliansi. 1997. Determinants of Sexual Behavior, Irish Journal of Sociology, vol.12, pp.121-133.

Arikunto. 2006. Prosedur Penelitian. Jakarta :Rineka Cipta 
Ariyatmi, S.(1991). Perspektif BK dan Penerapannya di Berbagai institusi. Semarang :Satya Wacana.

Bibby, Cyrill. (1957). Sex education:A Guide For Parent, Teacher and Youth Leader. Vol 15, pp.101-130.

Hastono, Sutarito Priyo.(2007). Analisis Data Kesehatan.FKM UI.

Hidayat, A. (2007). Riset Keperawatan dan Tehnik Penulisan Ilmiah. Jakarta:Salemba Medika

Hurlock, E. B. (1983). Psikologi Perkembangan Sepanjang Rentang Kehidupan (Edisi Kelima). Jakarta: Erlangga.

Imran, Irawati (2000). Modul Dua Perkembangan Seksual Remaja Keluarga Berencana Indonesia.

Kaplan \& Sadock. (1988). Sinopsis Psikiatri. Jilid 2. Binarupa Aksara : Jakarta.

Kementerian Kesehatan RI. (2012). Data dan Informasi Kesehatan: Penyakit Menular.

Mar'at. (1991). Sikap Manusia Perubahan Serta Pengukurannya. Jakarta: Ghalia Indonesia.

Notoatmodjo, S. (2012). Metodologi penelitian kesehatan. Jakarta: PT. Rineka Cipta.

Nursalam. (2011). Konsep dan Menerapan Metodologi Penelitian Ilmu Keperawatan: Pedoman Skripsi, Tesis dan Instrumen Penelitian Keperawatan (edisi ke-2). Jakarta: Salemba Medika.

Pangkahila, W (1981). Media Litbang Kesehatan Perilaku Seksual dan
Permasalahan Remaja. Vol 11, pp.98.

Preasetyo, B., \& Junnah, L. M. (2012). Metodologi Penelitian Kuantitatif. Jakarta: PT. Raja Grafindo Persada.

Sarwono, S Wirawan (2003). Psikologi Remaja. Jakarta. Raja Grafindo Persada

Sastroasmoro, Ismael. (2011). Dasar-dasar Metodologi Penelitian Klinis Edisi ke-4. Jakarta: Sagung Seto.

Sugiyono. (2010). Memahami Penelitian Kualitatif. Bandung: CV. Alfabeta.

Wawan, A., \& Dewi, M. (2010). Teori \& Pengukuran Pengetahuan, Sikap dan Perilaku Manusia. Yogyakarta: Nuha Medika.

WHO. (2000). Global Adult Tobacco Survey: Indonesia Report 2000. 